\title{
GAPS 2030: Building a Global Access Movement for Sustainable Development
}

\author{
Florian Kaiser, Graeme Atherton, Catherine Millett, \\ Mary Tupan-Wenno, and Diana Wickham \\ Global Access to Post-Secondary Education (GAPS) Initiative: \\ A European Access Network (EAN) Project
}

\author{
Florian.Kaiser@gaps-education.org; \\ Graeme.Atherton@gaps-education.org; cmillett@ets.org; \\ mary@echo-net.nl; wickhamdiana@gmail.com
}

\begin{abstract}
In September 2015, the United Nations adopted the 2030 agenda including sustainable development goals, for the first time addressing access to all levels of education. This essay has two aims. Firstly, it will illustrate why access to post-secondary education is emerging as a major global concern and provide examples of access gaps. The second is to describe a young global initiative for access to post-secondary education, which could help to realize the United Nations' vision for lifelong learning.
\end{abstract}

Keywords: Access, Access to Post-Secondary Education, Access to Higher Education, GAPS, Education Policy, Social Movement, Global Access to Higher Education, Widening Higher Education Access for Underrepresented Groups, Diversity \& Inclusion in Higher Education

\section{Introduction}

In September 2015, the United Nations (UN) adopted the 2030 agenda for sustainable development and set new sustainable development goals (SDGs). In contrast to the UN Millennium Declaration, the UN will no longer focus solely on access to primary education (United Nations [UN], 2000) but seek to fulfill a vision of "equitable and universal access to quality education at all levels" (UN, 2015, p. 3). Goal Four of the 2030 SDGs aims to "ensure equal access for all women and men to affordable and quality technical, vocational and tertiary education, including university" (UN, 2015, p. 17). This article will consider the major challenges to be faced in making progress toward this goal and describe a new initiative that aims to support this progress.

Material published as part of this publication, either on-line or in print, is copyrighted by the Informing Science Institute and Preeminent Leadership and Research Solutions, LLC. Permission to make digital or paper copy of part or all of these works for personal or classroom use is granted without fee provided that the copies are not made or distributed for profit or commercial advantage AND that copies 1) bear this notice in full and 2) give the full citation on the first page. It is permissible to abstract these works so long as credit is given. To copy in all other cases or to republish or to post on a server or to redistribute to lists requires specific permission and payment of a fee. Contact Publisher@InformingScience.org to request redistribution permission.

\section{What is Access to Tertiary Education?}

The UN does not provide us with a definition of 'access' and it is clear that the term does not have a single universal meaning. We would support a comprehensive understanding such as that associated with the 'social dimension' work of the European Union (EU). Access is "a policy that aims both at the widening 
of participation in higher education to all sections of society, and at ensuring that this participation is effective (that is, in conditions which ensure that personal effort will lead to successful completion)" (Council of Europe, 1998, p. 21).

\section{Why Access to Tertiary Education Matters}

Post-secondary education is frequently pointed to as the gateway to economic and social prosperity for both individuals and countries in the 21 st century ("What are the social benefits of education," 2013). It is also one of the key social determinants of health (World Health Organization, 2013), linked to better health outcomes, increased happiness and higher levels of civic participation, as well as reduced crime rates and stronger social cohesion (Organisation for Economic Cooperation and Development [OECD], 2010).

Research done on cities has pointed to the significant economic and social impact of raising local achievement levels by even one percent, through the multiplier effect on economic and social outcomes ("CEOs for Cities," 2015). In an increasingly urbanized world, the potential of this investment would appear self-evident. In fact, the return to society on investments in education is increasingly well documented (OECD, 2011).

A shortfall of workers educated to postsecondary levels across the world is widely projected at 38-40 million by 2030 (McKinsey Global Institute, 2012). At the same time, youth unemployment has reached previously unknown levels. In a 2014 report (United Nations Populations Fund, 2014), the UN called on governments to invest in education and health care for young people to confront a worsening global youth unemployment crisis and improve living standards worldwide.

According to Maslen (2012) by 2025 some 262 million students will be in post-secondary education across the world. Today, 35 percent of young people will receive a first tertiary degree before they turn 30 (OECD, 2015). This percentage is expected to grow to 50 percent over the life span of these young people (OECD, 2015). But while more and more students are receiving an education beyond high school, these opportunities are not spread equally within and among populations (Minority Rights Group International, 2015). The available evidence suggests that across the world cultural, economic and social circumstance drive systematic inequalities in participation in post-secondary education (Asian Development Bank, 2012; Educational Policy Institute, 2010; "What are the social benefits of education", 2013).

\section{The Access Gaps}

Reducing inequalities in participation in tertiary education is a complex multi-layered challenge. Four key aspects of this challenge are described below:

\section{Data Shortages}

Building an accurate picture of the state of access to post-secondary education around the world is hampered by gaps in data within even the most developed nations. For example, the Eurydice Report (2015) notes the considerable variation that exists among EU countries in those characteristics of the student body that are monitored and at what stages. Migrant status data, for instance, is captured in 13 systems and data on student and staff ethnicity in only eight (Eurydice, 2015). At the global level, UNESCO (World Bank, 2013) cites the unavailability of enrollment data for 97 of 214 countries.

\section{The Weakness of the Global Access Community}

The access 'community' may be loosely defined as the body of policymakers, researchers, leaders of and professionals and practitioners from within education systems, student groups, community 
organizations, and other stakeholders engaged with the issue of widening access and ensuring success for students and populations in their respective countries who do not easily access tertiary education. The term 'community,' however, implies a common sense of identity and purpose that exists primarily in parts of Europe and North America, with few international links. Even in the most developed nations, the access community tends to be fragmented and lacks policy influence at the state and country levels.

\section{Stakeholder Exclusion}

The inclusion of students and young people as equal contributors in the development of higher education policies and programs that affect their education outcomes, and in the governance of higher education institutions, is a relatively new concept in most countries. The opinions of young people and students are generally excluded in favor of a top-down process that fails to adequately reflect the needs and realities of those affected (Klemencic, 2013). Some strong examples of how student movements have impacted on access issues exist in Europe and parts of North America (Schmidt, 2013). However, many countries lack the history, structure and encouragement for such developments.

\section{Gaps in Access to Critical Fields and Emerging Technologies}

Access to specific disciplines of study, including sciences, technology, engineering and mathematics (STEM fields), is unequal across the world (United Nations Educational, Scientific and Cultural Organization [UNESCO] Asia-Pacific Regional Bureau for Education \& Korean Women's Development Institute, 2015). A recent U.S. study, for example, found that while about $21 \%$ of male students earned credit in engineering and technology at the high school level, just $8 \%$ of female students did the same. White students were more likely than students of any other race to earn credits in either engineering or computer and information sciences (National Center for Education Statistics, 2015). A lack of preparation and prerequisites for STEM courses is the key limiting factor in whether students proceed to STEM studies in higher education (UNESCO AsiaPacific Regional Bureau for Education \& Korean Women's Development Institute, 2015; World Bank, 2012). Yet the demand for technology and innovation-related skills is growing rapidly.

The technology gap across the world's classrooms, institutions and communities is also a major factor in the context of Massive Online Open Courses (MOOCs) being seen increasingly as a great leveler of educational opportunity particularly in the developing world.

\section{The Global Access to Post-secondary Education (GAPS) Initiative}

The Global Access to Post-Secondary Education (GAPS) Initiative aims to build a global, engaged, and collaborative access community that will champion post-secondary education for all and transform student opportunity.

The GAPS Initiative recognizes education as a basic human right. All people, irrespective of sex, age, race, and ethnicity, including indigenous peoples, migrants, and persons with disabilities, should have access to lifelong learning opportunities that include higher education opportunities. Individuals should have the opportunity to develop their capacity both to participate and to succeed at the post-secondary level.

To build a collaborative global network, the GAPS Initiative is targeting four groups (GAPS, 2015a): (1) the existing 'access community' across the world, (2) higher education institutions and policy makers, (3) not-for-profit and voluntary sectors and civil society groups, and (4) indi- 
viduals and organizations that are not necessarily working at the forefront of the access movement but whose objectives are generally aligned with those of GAPS.

GAPS has identified five core strategies to address access to post-secondary education on a global level (GAPS, 2015b):

1. Address gaps in knowledge and awareness of access issues across the globe.

2. Build the collective capacity of the access community globally and locally.

3. Make the case for equity of access and student success through collective advocacy.

4. Serve as a catalyst for change and innovation through community engagement and mobilization.

5. Ensure that the voice of current and potential students and the student experience is central to these efforts.

\section{Taking a Long term View}

We still have a long way to go to be able to realize the UN vision of an "equitable and universal access to quality education at all levels" (UN, 2015, p. 3). Working to generate agreement on a common definition of access will be an important first step, without which it will be difficult to demonstrate significant achievements or progress on widening access and success and to build consensus on future action plans. Notwithstanding, we at GAPS are greatly encouraged by the inclusion of higher education access on the SDG agenda. Today, the level of inequality of access to quality higher education remains unacceptable and our ability to make progress in removing barriers to widening access and student success is hampered by daunting challenges. But this is not an unchangeable status quo.

The GAPS Initiative is an opportunity to tackle access issues beyond primary and secondary education through the creation of an access movement which takes into consideration global diversity and recognizes that change will be most effective if it is achieved through collaborative local efforts connected across the globe: an opportunity for global learning and local acting supported by an inclusive global dialogue. The GAPS initiative should be a valuable partner for the UN and others who aim to make a measurable impact on the issue of access to post-secondary education by 2030 .

\section{References}

Asian Development Bank. (2012). Access without equity? Finding a better balance in higher education in Asia. Retrieved from http://www.adb.org/sites/default/files/publication/29769/access-withoutequity.pdf

CEOs for Cities. (2015). The city dividend. Retrieved from https://ceosforcities.org/portfolio/citydividends/

Council of Europe. (1998). Recommendation No. R (98) 3 of the Committee of Ministers to member states on access to higher education. Strasbourg. Retrieved from http://www.coe.int/t/dg4/highereducation/resources/access $\% 20$ to $\% 20$ higher $\% 20$ education recommend ation.pdf

Educational Policy Institute. (2010). Global higher education rankings 2010: Affordability and accessibility in comparative perspective. Retrieved from http://www.educationalpolicy.org/pdf/global2005.pdf

Eurydice. (2015). Modernisation of higher education in Europe: Access, retention and employability 2014. Retrieved from http://eacea.ec.europa.eu/education/eurydice/documents/thematic reports/180EN.pdf

Global Access to Post-Secondary Initiative. (2015a). Target audience. Retrieved from http://www.gapseducation.org/about-us/target-audience/ 
Global Access to Post-Secondary Initiative. (2015b). Core strategies. Retrieved from http://www.gapseducation.org/about-us/core-strategies/

Klemencic, M. (2013, December 13). Student engagement - Between policy-making and scholarship. University World News. Retrieved from http://www.universityworldnews.com/article.php?story=20131210124920672

Maslen, G. (2012, February 19). Worldwide student numbers forecast to double by 2025. University World News. Retrieved from http://www.universityworldnews.com/article.php?story=20120216105739999

McKinsey Global Institute. (2012). The world at work: Jobs, pay and skills for 3.5 billion people. Retrieved from http://www.mckinsey.com/ /media/McKinsey/dotcom/Insights\%20and\%20pubs/MGI/Research/Labor \%20Markets/The\%20world\%20at\%20work/MGI-Global_labor_Full_Report_June_2012.ashx

Minority Rights Group International. (2009). Education Special: State of the World's Minorities and Indigenous Peoples. Retrieved from http://www.minorityrights.org/7948/state-of-the-worldsminorities/state-of-the-worlds-minorities-and-indigenous-peoples-2009.html

National Center for Education Statistics. (2015). High school longitudinal study of 2009. Retrieved from https://nces.ed.gov/pubsearch/pubsinfo.asp?pubid=2015037 rev

Organisation for Economic Co-operation and Development. (2010). Improving health and social cohesion through education. doi:10.1787/9789264086319-en

Organisation for Economic Co-operation and Development. (2011). Education at a glance 2011: OECD indicators. Retrieved from http://dx.doi.org/10.1787/eag-2011-en

Organisation for Economic Co-operation and Development. (2015). Education at a glance 2015: OECD Indicators. Retrieved from http://dx.doi.org/10.1787/eag-2015-en

Schmidt, F. M. (2013, May 23). Unbridled success: Germany's fee foes claim victory. Times Higher Education. Retrieved from https://www.timeshighereducation.com/news/unbridled-success-germanys-feefoes-claim-victory/2003928.article

United Nations Educational, Scientific and Cultural Organization [UNESCO] Asia-Pacific Regional Bureau for Education \& Korean Women's Development Institute. (2015). A complex formula: Girls and women in science, technology. Retrieved from http://unesdoc.unesco.org/images/0023/002315/231519e.pdf

United Nations. (2000). United Nations millennium declaration. New York. Retrieved from http://www.unmillenniumproject.org/documents/ares552e.pdf

United Nations. (2015). Transforming our world: The 2030 agenda for sustainable development. New York. Retrieved from http://www.un.org/ga/search/view_doc.asp?symbol=A/RES/70/1\&Lang=E

United Nations Population Fund. (2014). The power of 1.8 billion: Adolescents, youth and the transformation of the future. Retrieved from http://www.unfpa.org/sites/default/files/pub-pdf/EN-SWOP14Report_FINAL-web.pdf

What are the social benefits of education? (2013, January). OECD Education Indicators in Focus. Retrieved from http://www.oecd.org/education/skills-beyond-school/EDIF\%202013-N\%C2\%B010\%20\%28eng\%29--v9\%20FINAL\%20bis.pdf

World Bank. (2012). World development report 2012: Gender equality and development. Retrieved from https://openknowledge.worldbank.org/handle/10986/4391

World Bank. (2013). World development indicators. Retrieved from http://databank.worldbank.org/data/download/WDI-2013-ebook.pdf

World Health Organization. (2013). The economics of social determinants of health and health inequities: A resource book. Retrieved from http://apps.who.int/iris/bitstream/10665/84213/1/9789241548625_eng.pdf 


\section{Biographies}

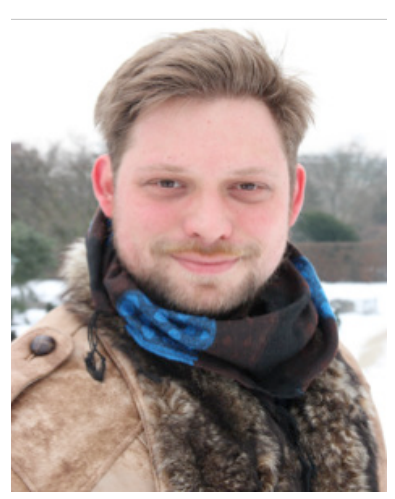

Florian Kaiser has been committed to higher education issues since the beginning of his studies. From September 2009 to August 2010 Florian was a member of the Executive Board of German Students' Union (fzs). From January 2011 to June 2012 he was elected to the Social Affairs Committee and the Gender Equality Cross Committee of the European Students' Union (ESU). From July 2012 to June 2013 he was a member of the Executive Committee of the European Students' Union (ESU). From January 2014 to December 2014 Florian was working as a Policy Assistant at the University of Liverpool for the SiS Catalyst project. Florian gained strong experience within the European context not only from participating in many higher education events, but also from participating in the BFUG WG on Social Dimension and as an expert in the European Parliament. Currently Florian works, not only for GAPS, but as a consultant and trainer in the field of social inclusion and social mobility through (higher) education.

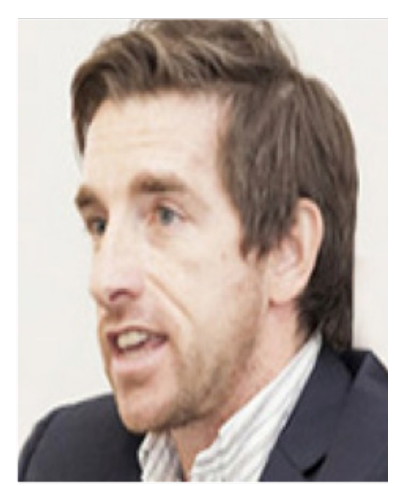

Graeme Atherton has been working in the field of access to postsecondary education. Based in London, he is the founder and Head of AccessHE which is a network of over 200 organizations working on extending access to higher education. He is also the founder and Director of NEON (National Education Opportunities in Education), which is the professional organization for access to higher education in England. He is also a Visiting Professor at both London Metropolitan University and Amity Business School, London and has produced over 120 publications and conference papers. Currently Graeme Atherton serves as the Chair of the GAPS Executive Committee.

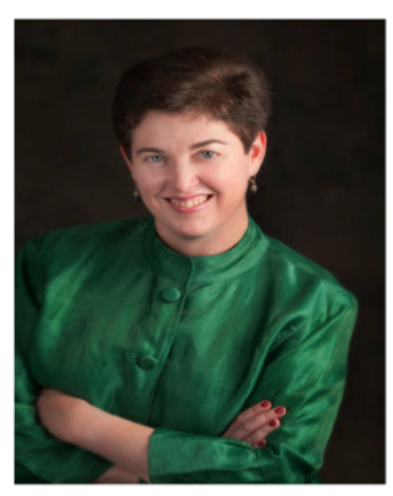

Catherine Millett is a senior research scientist in the Policy Evaluation and Research Center (PERC) at Educational Testing Service (ETS) in Princeton, NJ. Her research focuses on educational access, student performance and achievement, educational equity, and student financing for various population groups in the United States at the postsecondary educational level.

Millett directs the evaluation of the Princeton University Preparatory Program (PUPP), a rigorous academic and cultural enrichment program for high-achieving, low-income public high school students from Princeton area school districts to prepare for admission to and ongoing success within selective colleges and universities. For a decade, she coled the evaluation of the Goldman Sachs Foundation's Signature Initiative "Developing HighPotential Youth" and authored the 2009 report The Goldman Sachs Foundation: Developing High-Potential Youth A Return on Investment Study for U.S. Programs. Catherine Millet is a member of the GAPS Executive Committee. 


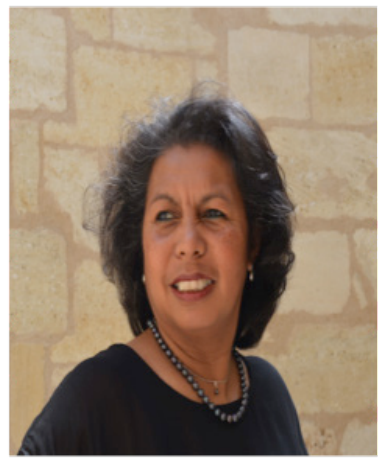

Mary Tupan-Wenno is the executive director of ECHO, Center for Diversity Policy in The Hague, the Netherlands. Her professional involvement on diversity and inclusion developments in (higher) education started when she was working for the government. She worked for the Dutch Ministry of Education Culture and Science as a policy advisor at the Department of Higher Education. She has more than 20 years of experience with policy and program development on the area of improving access and success of underrepresented groups in higher education, in particular ethnic minority students. She is a founding member of the European Access Network (1991) and is currently the President of the Executive Board of EAN. EAN provided a network to broaden her focus on the area of diversity and inclusion in higher education and to expand international collaboration. Mary Tupan-Wenno is a member of the GAPS Executive Committee.

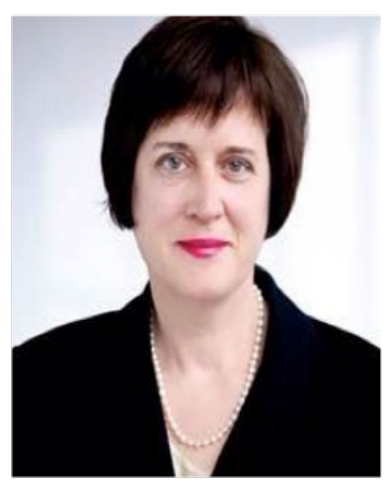

Diana Wickham is an advisor and consultant to education networks and foundations in the US and Europe, including GAPS, and to the non-profit sector within Canada through Civilis Group. From 20022010, she served as Executive Officer, Development, for the Canada Millennium Scholarship Foundation, where she spearheaded the creation of a national project designed to widen post-secondary access for first-generation and other underrepresented groups. She has organized two international conferences on post-secondary access and was the volunteer chair of the $1^{\text {st }}$ GAPS World Congress. Diana completed undergraduate studies in political science and communications and holds an MBA from IMD Lausanne. She currently lives in Montreal, Canada. 